\title{
PENGARUH UKURAN PERUSAHAAN DAN LEVERAGE TERHADAP NILAI PERUSAHAAN DENGAN PROFITABILITAS SEBAGAI VARIABEL MODERASI
}

\author{
Siwi Nur Khotimah \\ e-mail: siwi.khotimah24@yahoo.com \\ Rita Indah Mustikowati \\ Ati Retna Sari \\ Program Studi Akuntansi, Fakultas Ekonomika dan Bisnis Universitas Kanjuruhan, Malang
}

\begin{abstract}
ABSTRAK
Penelitian ini bertujuan untuk menguji dan menjelaskan pengaruh ukuran perusahaan dan leverage terhadap nilai perusahaan dengan profitabilitas sebagai variabel moderasi pada perusahaan Real Estate dan Property yang terdaftar di Bursa Efek Indonesia periode tahun 20162018. Jenis penelitian yang digunakan adalah explanatory research, dengan pengujian asumsi klasik, dan dianalisis menggunakan analisis regresi moderasian, serta menggunakan uji t. Jumlah sampel sebesar 32 perusahaan, dan metode pengambilan sampel yang digunakan yaitu purposive sampling. Variabel penelitian ini terdiri dari ukuran perusahaan dan leverage sebagai variabel independen, nilai perusahaan sebagai variabel dependen, dan profitabilitas sebagai variabel moderasi. Hasil analisis menunjukkan bahwa secara parsial ukuran perusahaan dan leverage tidak berpengaruh signifikan terhadap nilai perusahaan, profitabiliras berpengaruh negatif terhadap nilai perusahaan dan profitabilitas memperlemah pengaruh ukuran peruahaan terhadap nilai perusahaan dan profitabilitas memperkuat pengaruh leverage terhadap nilai perusahaan. Dalam penelitian ini dapat memberikan implikasi bagi suatu perusahaan untuk mempertimbangkan faktor-faktor ukuran perusahaan, leverage, dan profitabilitas, dan juga dapat dijadikan acuan oleh perusahaan-perusahaan lain dalam strategi bisnis, memahami aspek industri yang digeluti, dan lebih memperhatikan terhadap perkembangan lingkungan yang dapat mempengaruhi bisnis perusahaan sehingga dapat meningkatkan nilai perusahaan.
\end{abstract}

Kata kunci-Ukuran Perusahaan, Leverage, Profitabilitas, Nilai Perusahaan, dan Moderasi

\begin{abstract}
This study aims to examine and explain the effect of company size and leverage on firm value with profitability as a moderating variable in Real Estate and Property companies listed on the Indonesia Stock Exchange in the period 2016-2018. This type of research is explanatory research, testing classical assumptions, and analyzed using a moderated regression analysis, and using the test. The number of samples is 32 companies, and the sampling method used is purposive sampling. This research variable consists of company size and leverage as an independent variable, company value as the dependent variable, and profitability as a moderating variable. The analysis showed that partially company size and leverage had no significant effect on firm value, profitability had a negative effect on firm value and profitability weakened the effect of company size on firm value and profitability strengthened the effect of leverage on firm value.
\end{abstract}


In this study, it can provide implications for a company to consider factors of company size, leverage, and profitability, and can also be used as a reference by other companies in business strategy, understand aspects of the industry they are involved in, and pay more attention to the development of the environment that can affect the company's business so that it can increase the value of the company.

Keywords - Company Size, Leverage, Profitability, Firm Value, and Moderation

\section{PENDAHULUAN}

Persaingan bisnis antar perusahaan saat ini tidak terlepas dari pengaruh berkembangnya ekonomi, sosial politik, serta kemajuan teknologi. Setiap perusahaan harus mampu konsisten untuk memelihara atau bahkan semakin meningkatkan kinerjanya agar perusahaan mampu bersaing. Perusahaan membutuhkan modal yang lebih untuk memperluas bisnisnya. Dengan hal ini menjadi salah satu faktor perusahaan untuk masuk ke bursa efek (go public) dan melakukan penjualan saham ataupun mengeluarkan obligasi demi memperoleh modal dari para investor yang nantinya akan dimanfaatkan untuk menggembangan bisnisnya (Hartono, 2010).

Salah satu sektor usaha yang terdaftar di Bursa Efek Indonesia (BEI) yang memiliki persaingan cukup ketat adalah sektor real estate dan property. Indikator tersebut ditandai dengan rendahnya pertimbangan property membuat indeks harga saham menurun, awal tahun 2015 indeks saham property pada Bursa Efek Indonesia berada pada level 532,96. Indeks ini sempat naik pada level tertinggi pada akhir februari ke posisi 580,71. Kinerja sektor property ini kurang baik membuat indeks sahamnya pun turun.

Bahkan mencapai 496,91 pada penutupan perdagangan itu, ketua umum persatuan perusahaan realestat Indonesia (REI) Eddy Hussy mengatakan, Perlambatan disektor property terjadi karena rendahnya daya beli masyarakat, imbas dari kondisi ekonomi saat ini. Pada 2017 lalu, nilai kapitalisasi 35 persen saham dari 46 grub property yang tercatat di Bursa Efek Indonesia mencapai Rp 280 triliun. Bila nilai itu diakumulasikan hingga 100 persen, maka jumlahnya dipredeksi dapat mencapai Rp 840 triliun. Meningkatnya penjualan produk-produk properti seperti apartemen dan rumah. Penjualan apartemen pada kuartal I-2018 cukup stabil dibandingkan pada kuartal sebelumnya yaitu kuartal IV-2017, tingkat penjualan rata-rata mengalami kenaikan menjadi 64 persen.

Nilai perusahaan dapat dipengaruhi oleh ukuran perusahann (size). Ukuran perusahaan menyatakan bahwa "ukuran perusahaan dapat diartikan sebagai rata-rata total penjualan bersih untuk tahun yang bersangkutan sampai beberapa tahun" (Widianto, 2011). Perusahaan yang mempunyai ukuran perusahaan yang besar akan mudah dikenali oleh masyarakat, dan dianggap memiliki keuangan yang lebih baik daripada dengan perusahaan yang memiliki ukuran perusahaan yang kecil, hal tersebut mengakibatkan masyarakat akan percaya terhadap produk dan jasa yang dipasarkan oleh perusahaan yang memiliki ukuran perusahaan yang besar, dengan hal ini maka akan dapat meningkatkan penjualan perusahaan sehingga profitabilitas perusahaan yang meningkat, dan kesejahteraan pemegang saham yang menjadi tolak ukur nilai 
perusahaan akan meningkat.

Nilai perusahaan juga bisa dihubungkan dengan kebijakan hutang perusahaan (leverage). Leverage rasio yang digunakan untuk mengukur sejauh mana aktiva di biayai dari hutang. Menurut Ilham (Fahmi, Irham, 2014) rasio leverage merupakan rasio yang menunjukkan bagaimana kemampuan perusahaan untuk mengelola hutangnya untuk memperoleh keuntungan dan juga mampu melunasi kembali hutangnya. (Menurut kasmir ,2013) leverage merupakan rasio yang di gunakan untuk mengukur sejauh mana aktiva dibiayai dengan hutang.

Salah satu faktor yang juga mempengaruhi nilai perusahaan yaitu oleh dengan besar kecilnya profitabilitas yang dihasilkan oleh perusahaan. Profitabilitas sebagai alat ukur untuk menilai kemampuan perusahaan dalam mencari keuntungan. Rasio yang tunggi menunjukkan bahwa kinerja manajemen meningkatkan dalam mengelola sumber dana pembiyaan operasional efektif untuk menghasilkan laba bersih. (Kusumajaya, 2011).

Hasil penelitian yang dilakukan Menurut (Pratama dan Wikuana, 2016) Ukuran Perusahaan berpengaruh positif signifikan terhadap Nilai Perusahaan. Dan hasil penelitian (Nurmiati dkk, 2019) menunjukkan bahwa ukuran perusahaan memiliki dampak yang signifikan terhadap nilai perusahaan. Sedangkan hasil penelitian yamg dilakukan oleh (Dewi dan Wirajaya, 2013) menunjukkan bahwa ukuran perusahaan tidak berpengaruh terhadap nilai perusahaan. Hasil penelitian yang dilakukan oleh (Vaeza dan Hapsari, 2015) menyatakan bahwa Leverage berpengaruh positif terhadap nilai perusahaan. Namun dipenelitian (Sari dan Abundanti, 2014) menyatakan bahwa leverage berpengaruh negative terhadap nilai perusahaan. Dan penelitian (Nurmiati dkk, 2019) menyatakan bahwa leverage tidak berpengaruh signfikan terhadap nilai perusahaan.

Hasil Penelitian yang dilakukan Pratama dan Wiksuana (2016) menyatakan bahwa Profitabilitas secara parsial berpengaruh positif signifikan terhadap Nilai Perusahaan.Hasil dari (Hendraliany, 2019) menyatakan bahwa profitabilitas berpengaruh positif terhadap nilai peusahaan dan dapat diterima. Namun hasil penelitian yang dilakukan (Putri dan Welas, 2019) menyatakan bahwa profitabilitas tidak berpengaruh terhadap nilai perusahaan. Dan menurut hasil penelitian (Apriliyanti dkk, 2019) menyatakan bahwa Profitabilitas tidak berpengaruh positif terhadap nilai perusahaan.Menurut (Amin Wijoyo, 2018) menyatakan bahwa Profitabilitas berpengaruh tidak signifikan terhadap nilai perusahaan.

Berdasarkan hasil penelitian tersebut dapat disimpulkan bahwa tidak ada kekonsistenan dalam penelitian tersebut, sehingga penelitian ini bermaksud meneliti kembali dengan menambahkan variabel moderasi, yaitu profitabilitas sebagai Moderated Regression Analysis (MRA), maka penelitian ini, penulis akan menguji kembali persoalan yang memicu pada hasil penelitian terdahulu dengan judul sebagai berikut: "Pengaruh Ukuran Perusahan dan Leverage terhadap Nilai Perusahaan dengan profitabilitas sebagai Variabel Moderasi"

Copyright (C JRMA 2020 e-ISSN. 2715-7016 


\section{TINJAUAN PUSTAKA}

\section{Theory Agency}

Menurut teori keagenan menjelaskan mengenai dua pelaku ekonomi yang saling bertentangan yaitu prinsipal dan agen. Hubungan keagenan merupakan suatu kontrak dimana satu atau lebih orang (prinsipal) memerintahkan orang lain (agen) untuk melakukan suatu jasa atas nama prinsipal dan memberikan wewenang kepada agen membuat keputusan yang terbaik bagi prinsipal (Ichsan, R, 2013).

\section{Theory Signaling}

Teori signal menjelaskan bagaimana suatu perusahaan memberikan dorongan untuk memberikan informasi kapada pengguna laporan keuangan. Dorongan perusahaan dalam memberi informasi mengenai asimetri informasi antara perusahaan dan pihak luar karena perusahaan mengetahui lebih banyak mengenai perusahaan dan prospek yang akan dating dari pada pihak investor dan kreditor (Brigham dan Hosuton, 2014) perusahaan yang memiliki profitabilitas yang tinggi dapat menunjukkan sinyal prospek perusahaan yang baik dimasa mendatang.

\section{Nilai Perusahaan}

Perusahaan adalah sebuah organisasi yang mengkombinasikan atau mengorganisasikan berbagai sumber daya dengan tujuan untuk memproduksi barang atau jasa untuk dijual. Tujuan perusahaan menurut theory of the firm adalah memaksimalkan nilai perusahaan (value of the firm). Artinya, memaksimalkan nilai suatu perusahaan menjadi sangat penting bagi perusahaan, karena dapat memaksimalkan kemakmuran pemegang saham yang tercermin dari harga saham perusahaan. Menurut (Agus Sartono 2010) Nilai perusahaan adalah harga jual sebuah perusahaan sebagai suatu bisnis yang sedang beropeasi.

\section{Profitabilitas}

profitabilitas adalah suatu kemampuan perusahaan dalam memperolah laba atau keuntungan dalam hubungannya dengan penjualan, aktiva maupun modal sendiri yang dinyatakan dengan presentase. Keuntungan yang diraih perusahaan adalah cerminan kinerja perusahaan dalam menjalankan usahannya.Menurut (Kasmir, 2014).

\section{Leverage}

Leverage rasio yang digunakan untuk mengukur sejauh mana aktiva di biayai dari hutang. Menurut (Fahmi, Irham, 2014) rasio leverage merupakan rasio yang menunjukkan bagaimana kemampuan perusahaan untuk mengelola hutangnya untuk memperoleh keuntungan dan juga mampu melunasi kembali hutangnya.

\section{PERUMUSAN HIPOTESIS}

1. H1 : ukuran perusahaan berpengaruh terhadap nilai perusahaan

2. H2: leverage berpengaruh terhadap nilai perusahaan

3. H3: profitabilitas berpengaruh terhadap nilai perusahaan

4. H4: profitabilitas memoderasi ukuran perusahaanterhadap nilai perusahaan

5. H5: profitabilitas memoderasi leverage terhadap nilai perusahaan 


\section{METODE PENELITIAN}

Jenis data yang digunakan yaitu data sekunder berupa laporan keuangan perusahaan manufaktur pada tahun 2016-2018. Metode pengumpulan data berupa dokumentasi dengan mengakses www.idx.co.id. Populasi penelitian yaitu seluruh perusahaan Real Estate dan Property yang terdaftar di BEI periode tahun 2016-2018 sebesar 96 perusahaan. Teknik pengambilan anggota sampel menggunakan purposive sampling, yang merupakan penentuan sampel dengan kriteria-kriteria tertentu, yaitu 1) Perusahaan real estate dan property yang terdaftar di Bursa Efek Indonesia pada tahun 2016-2018. 2) Perusahaan real estate dan property yang mempublikasikan laporan keuangan secara berturut-turut pada tahun 2016-2018 di Bursa Efek Indonesia. 3) Perusahaan real estate dan property yang memperoleh laba pada periode 2016-2018. Berdasarkan kriteria tersebut, perusahaan yang memenuhi kriteria dan dijadikan sampel penelitian sebesar 36 perusahaan.

\section{Teknik Analisis Data}

Moderated regression analysis (MRA) adalah pendekatan analitik yang mempertahankan integritas sampel dan memberikan dasar untuk mengontrol pengaruh variabel moderator Menurut Ghozali (2013:229). Moderated regression analysis dinyatakan dalam bentuk model persamaan sebagai berikut :sebagai berikut:

$$
Y=\beta_{0}+\beta_{1} X_{1}+\beta_{2} X_{2}+\beta_{3} X_{3}+\beta_{4} X_{1} \cdot X_{3}+\beta_{5} X_{2} X_{3}+e
$$

\section{Keterangan:}

$$
\begin{aligned}
& \mathrm{Y} \quad=\text { Nilai Perusahaan } \\
& \mathrm{B}_{0} \quad=\text { Konstanta } \\
& \mathrm{B}_{1} \ldots . . . \\
& \mathrm{B}_{5}=\text { Koefisien Regresi } \\
& \mathrm{X}_{1} \quad=\text { Ukuran } \\
& \text { Perusahaan } \\
& \mathrm{X}_{2} \quad=\text { Leverage } \\
& \mathrm{X}_{3} \quad=\text { Profitabilitas } \\
& \mathrm{e} \quad=\text { Variabel Pengganggu }
\end{aligned}
$$

Analisis regresi yang digunakan perlu dilakukan pengujian asumsi klasik. Asumsi klasik adalah suatu pengujian hipotesis yang digunakan suatu penelitian yang menunjukkan model regresi tersebut layak atau tidak untuk dilakukan ke pengujian selanjutnya.

\section{HASIL DAN PEMBAHASAN}

\section{Uji Asumsi Klasik}

\section{Uji Multikolinieritas}

Hasil uji asumsi klasik multikolinieritas dengan menggunakan pendekatan VIF (Variance Inflation Faktor) menunjukkan bahwa nilai VIF semua variabel kurang dari 10 
dan nilai Tolerance lebih dari 0,1 sehingga tidak terjadi multikolinieritas.

\begin{tabular}{c|c|c|c}
\multicolumn{3}{|c}{ Table Hasil Uji Asumsi Klasik Multikolinieritas } \\
Variabel & $\begin{array}{c}\text { Nilai } \\
\text { Toleranc } \\
\mathrm{e}\end{array}$ & Nilai VIF & Simpulan \\
\hline X1_SZ & .978 & 1.022 & $\begin{array}{c}\text { Tidak terjadi } \\
\text { multikolinieritas }\end{array}$ \\
\hline X2_DER & .320 & 3.122 & $\begin{array}{c}\text { Tidak terjadi } \\
\text { multikolinieritas }\end{array}$ \\
\hline X3_PROF & .208 & 4.811 & $\begin{array}{c}\text { Tidak terjadi } \\
\text { multikolinieritas }\end{array}$ \\
\hline X1X3 & .728 & 1.374 & $\begin{array}{c}\text { Tidak terjadi } \\
\text { multikolinieritas }\end{array}$ \\
\hline X2X3 & .135 & 7.428 & $\begin{array}{c}\text { Tidak terjadi } \\
\text { multikolinieritas }\end{array}$
\end{tabular}

2. Uji Autokorelasi

Hasil uji asumsi klasik autokorelasi menunjukkan bahwa nilai Durbin Watson sebesar 1.869 terletak diantara 1,55-2,46. Hal tersebut mengindikasikan bahwa tidak terjadi autokorelasi.

\begin{tabular}{|l|r|r|r|r|r|}
\hline Model & $\mathrm{R}$ & R Square & $\begin{array}{l}\text { Adjusted } \\
\mathrm{R} \\
\text { Square }\end{array}$ & $\begin{array}{c}\text { Std. Error of } \\
\text { the Estimate }\end{array}$ & $\begin{array}{c}\text { Durbin- } \\
\text { Watson }\end{array}$ \\
\hline 1 & $.449 \mathrm{a}$ & .201 & .157 & .60672 & 1.869 \\
\hline
\end{tabular}

\section{Uji Heteroskedastisitas}

Hasil uji asumsi klasik heteroskedastisitas menunjukkan bahwa scatter plot tidak

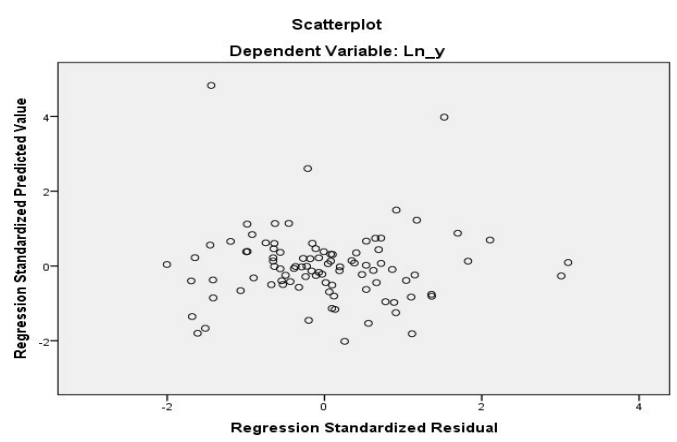

membentuk suatu gambar/pola tertentu, sehingga tidak terjadi heteroskedastisitas.

\section{Uji Normalitas}

Hasil uji asumsi klasik normalitas menunjukkan bahwa nilai Asymp Sig (2-tailed) sebesar 0.200 melebihi 0.05 , hal ini menunjukkan bahwa variabel pengganggu/variabel yang tidak diteliti memiliki distribusi normal. 


\section{Hasil Analisis Regresi Moderasian}

Hasil analisis regresi moderasian dapat dibuat pesamaan regresi sebagai berikut:

$$
\begin{aligned}
& Y=\beta_{0}+\beta_{1} X_{1}+\beta_{2} X_{2}+\beta_{3} X_{3}+\beta_{4} X_{1} X_{3}+\beta_{5} X_{2} X_{3}+e \\
& Y=0.712+0.855 X_{1}+0.139 X_{2}+0.004 X_{3}+0.020 X_{1} . X_{3}+0.001 X_{2} . X_{3}+
\end{aligned}
$$

Selanjutnya di ringkas pada tabel 1 sebagaai berikut:

Tabel 1 Hasil Analisis Regresi Moderasian

\begin{tabular}{|l|l|l|l|}
\hline Variabel & $\begin{array}{l}\text { Koefisisen } \\
\text { regresi }\end{array}$ & $\begin{array}{l}\text { Nilai } \\
\text { Sign }<0.05\end{array}$ & Kesimpulan \\
\hline Variabel X1 (Size) & -.058 & .855 & Tidak Berpengaruh \\
\hline Variabel X2 (leverage) & -.177 & .139 & Tidak Berpengaruh \\
\hline Variabel X3 (Profitabilitas) & -.283 & .004 & Berpengaruh \\
\hline Variabel X1*X3 & -.186 & .020 & Berpengaruh \\
\hline Variabel X2*X3 & .360 & .001 & Berpengaruh \\
\hline Nilai R-square $=0.201$ & \multicolumn{2}{l}{} \\
\hline
\end{tabular}

Berdasarkan persamaan regresi dan tabel 1 di atas dapat dijelaskan sebagai berikut:

1. Koefisien regresi (beta $=\S$ ) atas variabel ukuran perusahaan (X1) bertanda negatif 0.058. Hal tersebut menunjukkan bahwa variabel Ukuran Perusahaan berhubungan negatif dengan variabel nilai perusahaan. Artinya, jika nilai variabel ukuran perusahaan dinaikkan 1 satuan, maka nilai variabel nilai perusahaan akan mengalami penurunan sebesar -0.058 satuan. Dengan asumsi variabel lain tidak berubah.

2. Koefisien regresi (beta= $\$$ ) atas variabel leverage $(X 2)$ bertanda negative ---0.177. Hal tersebut menunjukkan bahwa variabel leverage berhubungan negatif dengan variabel nilai perusahaan. Artinya, jika nilai variabel leverage dinaikkan 1 satuan, maka nilai variabel nilai perusahaan akan menurun sebesar -0.177 satuan. Dengan asumsi variabel lain tidak berubah.

3. Koefisien regresi (beta= $=$ ) atas variabel profitabilitas (X3) bertanda negatif -0.283 satuan. Hal tersebut menunjukkan bahwa variabel profitabilitas berhubungan negatif dengan variabel nilai perusahaan. Artinya, jika nilai variabel profitabilitas dinaikkan 1 satuan, maka nilai variabel nilai perusahaan akan menurun sebesar -0.283 persen. Dengan asumsi variabel lain tidak berubah.

4. Koefisien regresi (beta= $=$ ) atas variabel moderasi (X1X3) bertanda negatif -0.186 . Hal tersebut menunjukkan bahwa variabel moderasi (interaksi ukuran perusahaanprofitabilitas) berhubungan negatif dengan variabel nilai perusahaan. Artinya, jika nilai variabel X1X3 dinaikkan 1 persen, maka nilai variabel nilai perusahaan akan mengalami penurunan -0.186 persen. dengan asumsi variabel lain tidak berubah.

5. Koefisien regresi (beta $=\Omega$ ) atas variabel moderasi $(X 2 X 3)$ bertanda positif 0.360 . Hal tersebut menunjukkan bahwa variabel moderasi (interaksi leverage-profitabilitas) berhubungan positif dengan variabel nilai perusahaan. Artinya, jika nilai variabel X2X3 dinaikkan 1 satuan, maka nilai variabel nilai perusahaan akan naik 0.360 
persen. dengan asumsi variabel lain tidak berubah.

6. Nilai $R-0.201$, menunjukkan bahwa perubahan variabel nilai perusahaan 20.1 persen dipengaruhi oleh variabel ukuran perusahaan, leverage dan profitabilitas. Sedangkan sisanya sebesar 79.9 persen dipengaruhi oleh variabel lain.

\section{HASIL UJI HIPOTESIS}

\section{Hasil Uji Hipotesis Pertama}

Hasil uji hipotesis pertama disajikan pada lampiran dan diringkas pada tabel 4.6 di atas, menunjukkan bahwa nilai signifikansi uji-t atas variabel ukuran perusahaan sebesar 0.885 lebih besar dari alpa 0.05 atau 5\%. Hal tersebut berarti bahwa secara parsial variabel ukuran perusahaan tidak ada pengaruh yang signifikan terhadap variabel nilai perusahaan. Sehingga hipotesis pertama yang menyatakan bahwa ukuran perusahaan tidak memiliki yang signifikan pengaruh terhadap nilai perusahaan. Maka hipotesis pertama ditolak.

\section{Hasil Uji Hipotesis Kedua}

Hasil uji hipotesis kedua disajikan pada lampiran dan diringkas pada tabel $4.6 \mathrm{di}$ atas, menunjukkan bahwa nilai signifikansi uji-t atas variabel leverage sebesar 0.139 lebih besar dari alpa 0.05 atau 5\%. Hal ini menunjukkan bahwa secara parsial variabel leverage tidak ada pengaruh yang signifikan terhadap variabel nilai perusahaan. Sehingga hipotesis kedua yang menyatakan bahwa leverage tidak memiliki pengaruh yang signifikan terhadap nilai perusahaan terhadap nilai perusahaan. Maka hipotesis kedua ditolak.

\section{Hasil Uji Hipotesis Ketiga}

Hasil uji hipotesis ketiga disajikan pada lampiran dan diringkas pada tabel $4.6 \mathrm{di}$ atas, menunjukkan bahwa nilai signifikansi uji-t atas variabel profitabilitas sebesar 0.004 lebih kecil dari alpa 0.05 atau 5\%. Hal tersebut berarti bahwa variabel profitabilitas memiliki pengaruh positif terhadap variabel nilai perusahaan. Sehingga hipotesis ketiga yang menyatakan bahwa profitabilitas berhubungan negative terhadap nilai perusahaan.

\section{Maka hipotesis ketiga diterima. Hasil Uji Hipotesis Keempat}

Hasil uji hipotesis ketiga disajikan pada lampiran dan diringkas pada tabel $4.6 \mathrm{di}$ atas, menunjukkan bahwa nilai signifikansi uji-t atas variabel profitabilitas sebesar 0.004 lebih kecil dari alpa 0.05 atau 5\%. Hal tersebut berarti bahwa variabel profitabilitas memoderasi pengaruh variabel ukuran perusahaan terhadap variabel nilai perusahaan. Koefisien regresi $($ beta $=\beta$ ) yang sudah di standarisasi atas variabel profitabilitas bernilai 0.263 dan bertanda negatif, sehingga dapat diartikan bahwa variabel profitabilitas memperlemah pengaruh variabel ukuran perusahaan terhadap variabel nilai perusahaan. Dengan demikian, hipotesis ketiga yang menyatakan bahwa profitabilitas memperlemah pengaruh ukuran perusahaan terhadap nilai perusahaan diterima.

\section{Hasil Uji Hipotesis Kelima}

Hasil uji hipotesis keempat disajikan pada lampiran dan diringkas pada tabel 4.6 di atas, menunjukkan bahwa nilai signifikansi uji-t atas variabel profitabilitas sebesar 0.001 lebih kecil dari alpa 0.05 atau 5\%. Hal tersebut berarti bahwa variabel profitabilitas 
memoderasi pengaruh variabel leverage terhadap variabel nilai perusahaan.

Koefisien regresi (beta= $=$ ) yang sudah di standarisasi atas variabel profitabilitas bernilai 0.891 dan bertanda negatif, sehingga dapat diartikan bahwa variabel profitabilitas memperkuat pengaruh variabel leverage terhadap variabel nilai perusahaan. Dengan demikian, hipotesis keempat yang menyatakan bahwa profitabilitas memperkuat pengaruh leverage terhadap nilai perusahaan diterima.

\section{PEMBAHASAN}

Pengaruh ukuran perusahaan terhadap nilai perusahaan

Dari hasil pengujian tidak membuktikan terdapat pengaruh ukuran perusahaan terhadap nilai perusahaan. Hasil tersebut menunjukkan bahwa signifikasi uji-t nilai variabel ukuran perusahaan lebih besar dari nilai alpa dengan nilai koefisiennya bertanda negatif. Hal ini mengindikasikan bahwa ukuran perusahaan tidak berpengaruh terhadap nilai perusahaan. Dari pembahasan diatas dapat disimpulkan bahwa ukuran perusahaan yang besar belum tenntu bisa menjamin nilai perusahaanya tinggi, karena perusahaan besar mungkin belum tentu berani melakukan investasi baru terkait dengan ekspansi, sebelum kewajiban (hutang) sudah terlunasi, disisi lain dalam menanamkan modal investor tidak hanya memandang ukuran perusahaan akan tetapi investor masih banyak mempertimbangkan faktor- faktor lain nya yang menjaid pertimbangan investor dalam menyalurkan dananya. Seperti pertumbuhan maupun peningkatan laba perusahaan Hasil penelitian dapat disimpulkan bahwa hipotesis pertama tidak dapat diterima yang menduga bahwa ukurann perusahaan mempunyai pengaruh terhadap nilai perusahaan. Hasil ini konsisten dengan penelitian yang dilakukan oleh Dewi dan Wirajaya, (2013) menunjukkan bahwa ukuran perusahaan tidak berpengaruh pada nilai perusahaan. Namun Hasil ini tidak konsisten dengan penelitian yang dilakukan Pratama dan Wikuana, (2016) Ukuran Perusahaan berpengaruh positif signifikan terhadap Nilai Perusahaan.

\section{Pengaruh leverage terhadap nilai perusahaan}

Dari hasil pengujian tidak membuktikan terdapat pengaruh leverage terhadap nilai perusahaan. Hasil tersebut menunjukkan pada bab sebelumnya bahwa signifikasi uji-t nilai leverage lebih besar dari nilai alpa dengan nilai koefisiennya bertanda negative. Hal ini mengindikasikan bahwa leverage tidak berpengaruh terhadap nilai perusahaan. Dapat disimpulkan bahwa leverage yang diproksikan dengan DER tidak berpengaruh terhadap nilai perusahaan. Semakin tinggi nilai leverage semakin turun nilai perusahaan. Oleh karena itu penggunaan hutang harus dibatasi alangkah lebih baik juga jika manajemen lebih memanfaatkan pendanaan, Besar kecilnya leverage tidak ada hubungannya dengan nilai perusahaan atau dengan kata lain leverage tidak dapat dikelola untuk meningkatkan nilai perusahaan. Hasil penelitian dapat disimpulkan bahwa hipotesis kedua tidak dapat diterima yang menduga bahwa leverage mempunyai pengaruh terhadap nilai perusahaan. Hasil ini konsisten dengan penelitian yang Dan penelitian (Nurmiati, dkk, 2019) menyatakan bahwa leverage tidak berpengaruh signfikan terhadap nilai perusahaan. Namun penelitian ini tidak konsisten dengan penelitian yang dilakukan oleh (Vaeza dan Hapsari, 2015) menyatakan bahwa Leverage berpengaruh positif terhadap nilai perusahaan.

Copyright (C JRMA 2020 e-ISSN. 2715-7016

Hal | 9 


\section{Pengaruh profitabilitas terhadap nilai perusahaan}

Dari hasil pengujian membuktikan bahwa profitabilitas berpengaruh terhadap nilai perusahaan. Hasil tersebut menunjukkan bahwa signifikasi uji-t nilai profitabilitas lebih kecil dari alpa dengan koefisien bertanda negative. Hal ini mengindikasikan bahwa profitabilitas berpengaruh negatif terhadap nilai perusahaan. Jika profitabilitas meningkat maka nilai perusahaan mengalami penurunan. Hal ini dikarenakan oleh peningkatan profitabilitas perusahaan akan menjadi laba perlembar saham perusahaan meningkat, tetapi dengan peningkatan profitabilitas belum tentu harga saham perusahaan ikut meningkat sehingga apabila laba perlembar saham meningkat tetapi harga saham tidak meningkat maka itu akan membuat nilai perusahaan menurun. Hasil penelitian ini tidak konsisten dengan penelitian yang dilakukan Putri dan Welas, (2019) menyatakan bahwa profitabilitas tidak berpengaruh terhadap nilai perusahaan dan penelitian dari Hendraliany, (2019) menyatakan bahwa profitabilitas berpengaruh positif terhadap nilai peusahaan dan dapat diterima

\section{Profitabilitas Memperlemah Pengaruh Ukuran Perusahaan Terhadap Nilai Perusahaan} terdapat pengaruh dari variabel profitabilitas terhadap nilai perusahaan. Dari hasil pengujian membuktikan terdapat pengaruh profitabilitas terhadap nilai perusahaan. Hasil tersebut menunjukkan bahwa nilai signifikasi uji-t variabel moderasi (interaksi profitabilitas - ukuran perusahaan) lebih kecil dari nilai alpa dengan koefisien bertanda negatif. Sehingga jika variabel tersebut ditingkatkan maka variabel nilai perusahaan akan menurun. Dengan demikian profitabilitas mampu memoderasi hubungan ukuran perusahaan terhadap nilai perusahaan. Dengan kesimpulan hasil analisis berarti profitabilitas mampu memperlemah hubungan ukuran perusahaan terhadap nilai perusahaan. Hal ini menunjukkan hasil bahwa setiap peningkatan profitabilitas (ROA) tidak menjamin dengan diikuti peningkatan ukuran perusahaan maupun nilai perusahaan. Tindakan manajemen laba yang membuat laba terlihat lebih besar, menjadi alasan bagi investor untuk tidak hanya melihat rasio profitabilitas sebagai dasar keputusan membeli suatu sahamHasil ini konsisten dengan penelitian yang dilakukan Apriliyanti dkk, (2019) menyatakan bahwa Profitabilitas tidak berpengaruh positif terhadap nilai perusahaan. Namun Hasil ini tidak konsisten dari penelitian Hendraliany, (2019) menyatakan bahwa profitabilitas berpengaruh positif terhadap nilai peusahaan dan dapat diterima

\section{Profitabilitas Memperkuat Pengaruh Leverage Terhadap Nilai Perusahaan}

Dari hasil pengujian membuktikan terdapat pengaruh profitabilitas terhadap nilai perusahaan. Hasil tersebut menunjukkan bahwa nilai signifikasi uji-t variabel moderasi (interaksi profitabilitas - leverage) lebih kecil dari nilai alpa dengan koefisien bertanda positif. Sehingga jika variabel tersebut ditingkatkan maka variabel nilai perusahaan akan meningkat. Hasil tersebut menunjukkan bahwa ada pengaruh positif dan signifikan interaksi profitabilitas dengan leverage terhadap nilai perusahaan. Dengan 
demikian profitabilitas mampu memoderasi hubungan leverage terhadap nilai perusahaan. Dengan kesimpulan hasil analisis berarti profitabilitas mampu memperkuat hubungan ukuran perusahaan terhadap nilai perusahaan. dari pernyataan diatas dapat dinyatakan bahwa, dengan meningkatnya keuntungan atau laba dapat menutupi hutanghutang kepada pihak luar sehingga krbutuhan pendanaan dalam operasional perusahaan menjadi tidak tergangu, jadi jika perusahaan ingin memenuhi dana untuk operasional perusahaan yang tidak mampu didanai perusahaan sendiri. Maka perusahaan perlu meningkatkan keuntungan atau laba perusahaanya, karena profitabilitas merupakan pertimbangan beberapa jumlah pinjaman yang akan dilakukan. Pernyataan ini diperkuat dalam penelitian dari Hendraliany, (2019) menyatakan bahwa profitabilitas berpengaruh positif terhadap nilai peusahaan dan dapat diterima. Namun hasil tersebut tidak konsisten dengan penelitan Amin Wijoyo, (2018) menyatakan bahwa Profitabilitas berpengaruh tidak signifikan terhadap nilai perusahaan

\section{KESIMPULAN, IMPLIKASI DAN SARAN}

Berdasarkan pengujian dan penjelasan yang telah dilakukan, dapat disimpulkan bahwa secara parsial variabel ukuran perusahaan tidak berpengaruh terhadap nilai perusahaan, secara parsial variabel leverage tidak berpengaruh terhadap nilai perusahaan, profitabilitas berpengaruh negative terhadap nilai perusahaan, profitabilitass memperlemah pengaruh ukuran perusahaan terhadap nilai perusahaan, dan profutabilitas memperkuat pengaruh leverage terhadap nilai perusahaan.

Dalam penelitian ini dapat memberikan implikasi bagi suatu perusahaan untuk mempertimbangkan faktor-faktor ukuran perusahaan, leverage, dan profitabilitas, dan juga dapat dijadikan acuan oleh perusahaan-perusahaan lain dalam strategi bisnis, memahami aspek industri yang digeluti, dan lebih memperhatikan terhadap perkembangan lingkungan yang dapat mempengaruhi bisnis perusahaan sehingga dapat meningkatkan nilai perusahaan.

Berdasarkan kesimpulan diatas maka, saran yang dapat diberikan peneliti adalah sebagai berikut: Bagi Investor, ketika investor ingin menanamkan modalnya maka sebaiknya menganalisis variabel yang terkait nilai perusahaan yaitu variabel ukuran perusahaan, leverage dan profitabilitas, sebaiknya investor mempertimbangkan berbagai aspek ketika melakukan investasi, termasuk segala resiko yang kemungkinan terjadi pada perusahaan yang diinginkannya, investor juga harus lebih teliti dalam melihat nilai nilai perusahaan untuk mengetahui seberapa besar tingkat keberhasilan perusahaan tersebut.

Bagi Perusahaan, Perusahaan dalam meningkatkan nilai perusahaan perlu meningkatkan variabel ukuran perusahaan, leverage dan profitabilitas. Informasi yang diperoleh dari hasil penelitian diharapkan dapat digunakan sebagai bahan pertimbangan dalam mengambil keputusan serta 
Pengaruh debt to equity ratio dan current ratio terhadap nilai perusahaan dengan return on asset sebagai variabel intervening

membuat kebijakan dalam rangka meningkatkan nilai perusahan, nilai perusahaan dapat ditingkatkan dengan meningkatkan profit pada suatu perusahaan dimana manajemen perusahaan real estate dan property yang terdaftar di BEI tetap terjaga kestabilan return on asset agar para investor tetap percaya untuk berinvestasi pada perusahaan. Bagi Peneliti Selanjutnya, Sebaiknya peneliti selanjutnya melakukan penelitian pada sektor yang berbeda tidak hanya perusahaan real estate dan property saja, selain itu peneliti selanjutnya juga dapat menambahkan atau mengganti variabel-variabel lain yang dapat mempengaruhi nilai perusahaan serta beberapa variabel pengukur lainnya sehingga dapat memperkuat hasil-hasil penelitian yang telah dilakukan sebelumnya. Dan juga menggunakan periode penelitihan dengan tahun terbaru yang bertujuan untuk memberikan gambaran yang lebih luas dan terkini mengenai nilai perusahaan pada perusahaan Real Estate dan Property.

\section{DAFTAR PUSTAKA}

Agus Sartono. 2010. Manajemen Keuangan Teori dan Aplikasi. Edisi 4. Yogjakarta: BPFE

Ayu Sri Mahatma Dewi, Ary Wirajaya. 2013, Pengaruh Struktur Modal, Profitabilitas Dan Ukuran Perusahaan Pada Nilai Perusahaan, E-Jurnal Akuntansi Universitas Udayana, pp: 358-372, ISSN: 2302-8556 4.2

Amin Wijoyo, 2018), Faktor-Faktor Yang Mempengaruhi Nilai Perusahaan Pada Perusahaan Property Dan Real Estate Di Bursa Efek Indonesia. Universitas Tarumanagara. Jurnal Ekonomi/Volum XXIII,No. 01 Maret 2018: 48-61

Brigham, Eugene F., \& Houston, Joel F. 2013. Dasar-dasar Manajemen Keuangan, Buku Dua, Edisi 11. Jakarta: Salemba Empat

Fahmi, Irham, 2014.pengantar manajemen keuangan. Bandung:Alfabeta

Firdaus, M. 2010. Ekonometrika Suatu Pendekatan Aplikatif. Jakarta: Bumi Aksara

Ghozali, Imam. 2011. "Aplikasi Analisis Multivariate Dengan Program SPSS". Semarang: Badan Penerbit Universitas Diponegoro.

Hartono, Jogiyanto. 2010, Teori Portofolio dan Analisis Investasi. Yogyakarta : BPFE UGM.

Hermuningsih, Sri. 2013. Pengaruh Profitabilitas, Growth Opportunity, Sruktur Modal Terhadap Nilai Perusahaan Pada Perusahaan Publik Di Indonesia.

Yogyakarta: University of Sarjanawiyata Taman siswa Yogyakarta.

Hendraliany (2019) Pengaruh Profitabilitas, Ukuran Perusahaan, Pertumbuhan Perusahaan, Kebijakan Deviden Dan Keputusan Investasi Terhadap Nilai Perusahaan. Jurnal Ekonomika dan Manajemen Vol. 8 No. 1 April 2019 hlm. 47-58.

Ichsan, R. (2013, 12 Januari). Teori Keagenan (Agency Theory).

Kasmir. 2013. Analisis Laporan Keuangan. Rajawali Pers : Jakarta

Kasmir, 2014. Analisis Laporan Keuangan. Edisi satu. Cetakan Ketujuh. Jakarta: PT Raja Grafindo Persada.

Kusumajaya, D, K, 2011. Pengaruh Struktur Modal Dan Pertumbuhan perusahaan 
Pengaruh debt to equity ratio dan current ratio terhadap nilai perusahaan dengan return on asset sebagai variabel intervening terhadap profitabilitas dan nilai perusahaan pada perusahaan manufatur di Bursa Efek Indonesia. Tesis . Denpasar : Program Pasca Sarjana Universitas Udayana.

Nurmiati, Dkk (2019). analisis pengaruh ukuran perusahaan. Leverage, profitabilitas dan kebijakan deviden terhadap nilai perusahaan. E-JRA Vol. 08 No. 08 Agustus 2019 Fakultas Ekonomi dan Bisnis Universitas Islam Malang.

Pratama dan Wiksuana (2016). Pengaruh Ukuran Perusahaan Dan Leverage Terhadap Nilai Perusahaan Dengan Profitabilitas sebagai Variabel Mediasi. E-Jurnal Manajemen Unud, Vol. 5, No. 2, 2016: 1338-1367 ISSN : 2302-8912.

Sari, Putu Indah Purnama dan Abundanti, Nyoman. 2014. Pengaruh Pertumbuhan Perusahaan Dan Leverage Terhadap Profitabilitas Dan Nilai Perusahaan. E-Journal Universitas Udayana.Vol.3 No. 5.Denpasar: Universitas Udayana.

Sartono, Agus. 2010. Manajemen Keuangan Teori dan Aplikasi. Yogyakarta: BPFEE

Sugiyono. 2013 . Metode Penelitian Kuantitatif, Kualitatif dan RED. Bandung: Alfabeta.

Sugiyono. (2017). Metode Penelitian Kuantitatif, Kualitatif, dan REDD. Bandung : Alfabeta, CV.

Utami Putrid an Welas (2019). Pengaruh Current Ratio, Return On Asset, Total Asset Turnover dan Debt To Equity Ratio Terhadap Nilai Perusahaan". Jurnal Akuntansi dan Keuangan FEB Universitas Budi Luhur Vol. 8 No. 1 April 2019 ISSN: 22527141.

Vaeza, Hapsari (2015). pengaruh ukuran perusahaan, profitabilitas, leverage, dan kebijakann deviden terhadap nilai perusahaan. ISSN : 2355-9357 e-Proceeding of Management : Vol.2, No.3 Desember 2015.

Vivi Apriliyanti, Hermi, Vinola Herawati (2019). pengaruh kebijakan hutang, kebijakan deviden, profitabilitas, pertumbuhan penjualan dan kesempatan investasi terhadap nilai perusahaan. Jurnal Magister Akuntansi Trisakti. ISSN : 2339-0859 (Online) Vol. 6 No. 2 September 2019 : 193-214.

Widianto, Hari Suryono. 2011. Pengaruh Profitabilitas, Likuiditas, Leverage, Aktivitas, Ukuran Perusahaan, dan Corporate Governance terhadap Praktik Pengungkapan Sustainability Report. Fakultas Ekonomika dan Bisnis Universitas Diponegoro

Zulbiadi Latief. 2018. Daftar Perusahaan Sekuritas yang Terdaftar di OJK E BEI 